\title{
A cross-sectional study of diseases prevailing in an orthopaedic OPD at a tertiary care hospital in the Mumbai metropolitan region
}

\author{
Girish Rathod, Pushkar Borole*, Chandan Shetty, Nitin Raut, \\ Namrata Britoo, Vijaykumar Gawali
}

Department of Orthopaedics, Bhaktivedanta Hospital and Research Institute, Mira Road, Mumbai, Maharashtra, India

Received: 22 November 2021

Revised: 17 December 2021

Accepted: 20 December 2021

\author{
*Correspondence: \\ Dr. Pushkar Borole, \\ E-mail: drpushkarborole@gmail.com
}

Copyright:@ the author(s), publisher and licensee Medip Academy. This is an open-access article distributed under the terms of the Creative Commons Attribution Non-Commercial License, which permits unrestricted non-commercial use, distribution, and reproduction in any medium, provided the original work is properly cited.

\begin{abstract}
Background: The orthopaedic out-patient department of a tertiary care hospital plays a crucial role in the health care system as it attends to a large number of patients. The goal of the study is to observe the etiological patterns of common issues that prevail in an Orthopaedics OPD of a hectic tertiary care hospital, which could in turn help to understand the distribution of illnesses in a particular geographical area.

Methods: Analysis of 1605 patient records was carried out from the period July 2020 to December 2020, to assess the orthopaedic out-patient load and prevailing diseases. Initial medical records of the patients were analyzed and the data collected were subjected to statistical analysis using IBM SPSS software version 1.0.

Results: The primary diagnosis of patients visiting the orthopaedic OPD during the Covid-19 period are observed to be as follows: acute and chronic back ache (27.29\%), arthritis (26.23\%), joint stiffness (10.03\%), ligamentous sprains (9.84\%), neck-related problem (6.92), tendinopathies and enthesopathies (6.60\%), non-specific body aches $(5.11 \%)$, post-operative follow-up (4.05\%), bone fractures $(2.37 \%)$, soft tissue injuries $(0.93 \%)$, and neuropathies $(0.62 \%)$.

Conclusions: The study presenting the overview of diseases prevailing in an orthopaedic OPD in a tertiary care center could help in formulating better prevention and treatment strategies to overcome such medical conditions irrespective of the presence of a pandemic.
\end{abstract}

Keywords: Orthopaedic OPD, COVID-19, Backache, Arthritis, Joint stiffness, Epidemiology

\section{INTRODUCTION}

The distribution of illnesses is a critical predictor of health in a particular area; it is an essential aspect for electing vital drugs and making plans for the finances for remedy in that particular sector. This distribution can be understood by the presentation of the patients coming to a hospital's out-patient department (OPD). ${ }^{1}$ Orthopedics is a massive and sophisticated field of medication that caters not solely to patients with fractures and soft tissue injuries but also conjointly musculoskeletal conditions, and such conditions contribute to a huge load of the orthopaedic OPD of any hospital. ${ }^{2}$ The prevalence and pattern of orthopaedic complaints can also additionally range in distinctive areas because of racial, environmental, or geographical peculiarity with inside the region. It is vital to recognize approximately the quantity of the hassle, the elements related to it, so as to design and put into effect any curative/safety measure for a specific hassle affecting the population in a particular area. An orthopaedic OPD has an enormous rush of patients. Generally, various orthopedic problems take some time to heal before the patient can return to duty, increasing the financial or professional burden on the 
patient. Most cases of trauma require hospitalization followed by surgery; patients are discharged after a few days, to follow orthopedic OPD for further evaluation of healing or to check for complications if they develop. ${ }^{3}$ The present study gives baseline statistical information on the modern-day orthopedic outpatient load with a view to spotlight the more common orthopaedic issues found in orthopedic clinics so that changes may be brought to enhance the great of care. Furthermore, the suggested information could be useful to the policymakers for planning guidelines for resolving the issues relating to the increasing load of orthopedic issues.

\section{Objectives}

The present study aims to discover the pattern and type of presentation of the sufferers observed in the orthopaedic OPD during the COVID-19 period by the following means; understanding the magnitude and impact of a particular type of orthopaedic problem prevailing in the region and identifying the preventable risk factors of the observed diseases.

\section{METHODS}

The study conducted was a cross-sectional one, carried out in the outpatient department of orthopedics of Bhaktivedanta hospital and research institute, Mumbai, India. Patients of all age groups who attended the orthopaedic OPD were included in our study.

\section{Study design, location and duration}

Current study was a retrospective study, initial medical record review. This was a hospital-based study carried out in the outpatient department of orthopaedics of Bhaktivedanta hospital and research institute, Mumbai, India. The present study was conducted from July 2020 to December 2020 (6 months).

\section{Sample size, sampling technique and subjects selection method}

In present study 1605 subjects were selected by consecutive sampling technique. Data of all patients who visited the orthopaedicout-patient department from July 2020 to December2020 was retrieved for the study.

\section{Exclusion criteria}

Patients whose data was not available and all patients admitted in the orthopaedic in-patient department were excluded from the study.

\section{Procedure}

For analysis, only those patients' data were taken into consideration that fulfilled the eligibility criteria.

\section{Statistical analysis}

IBM SPSS software version 1.0 was used for the statistical data analysis.

\section{RESULTS}

Out of the 2000 cases, 395 cases had non-specific diagnoses, hence excluding those cases, a total of 1605 cases were included in the study. Mean age of the patients were found to be 51 (SD-14) years. The primary diagnoses observed were as follows: acute and chronic back ache $(27.29 \%)$, arthritis $(26.23 \%)$, joint stiffness $(10.03 \%)$, ligamentous sprains $(9.84 \%)$, neck-related problem (6.92), tendinopathies and enthesopathies $(6.60 \%)$, nonspecific body aches $(5.11 \%)$, post-operative follow-up $(4.05 \%)$, bone fractures $(2.37 \%)$, soft tissue injuries $(0.93 \%)$, and neuropathies $(0.62 \%)$ as shown in (Table 2). All diagnoses were found to be higher among male patients (Figure 1).

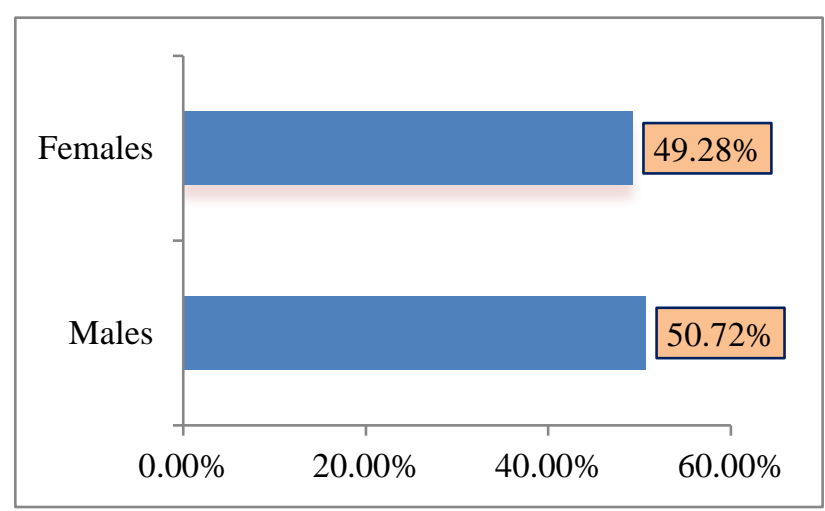

Figure 1: Gender distribution of patients attending the orthopaedic OPD.

Table 1: Age-wise distribution of illnesses observed in the present study.

\begin{tabular}{|l|l|}
\hline Diagnosis & $\begin{array}{l}\text { Observed in age } \\
\text { group }\end{array}$ \\
\hline Acute and chronic backache & $13-81$ \\
\hline Neck-related problems & $21-76$ \\
\hline Arthritis & $44-85$ \\
\hline $\begin{array}{l}\text { Tendinopathies and } \\
\text { Enthesopathies }\end{array}$ & $29-51$ \\
\hline Ligamentous sprains & $20-56$ \\
\hline Sports injuries & $23-43$ \\
\hline Post-operative follow-up & $26-78$ \\
\hline Joint stiffness & $49-71$ \\
\hline Bone fractures & $7-64$ \\
\hline Non-specific body ache & $40-75$ \\
\hline Neuropathies & $28-55$ \\
\hline
\end{tabular}

The most common illness was found to be back pain observed in age group 13-81 years. The second most common problem was found to be arthritis observed in 
age group 44-85 years. The least complaint found to be was neuropathies, followed by sports injuries.

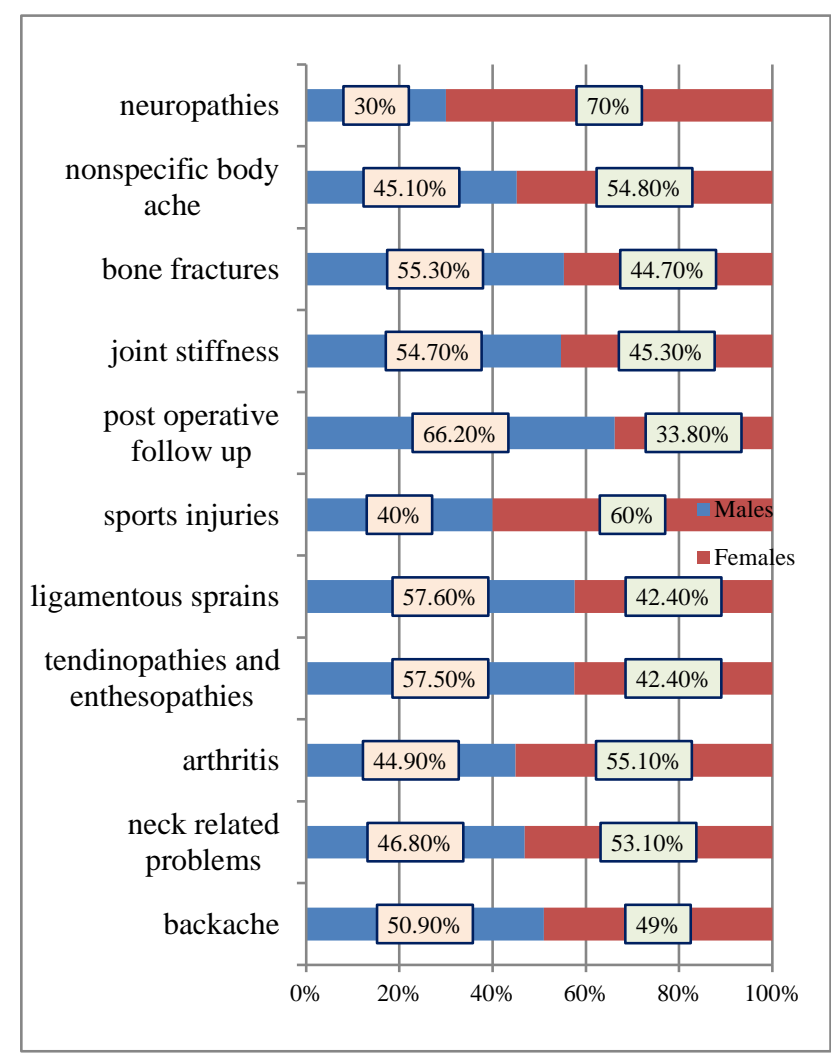

Figure 2: Gender-wise distribution of patients with respect to their initial diagnosis.

\section{DISCUSSION}

1605 patients were included in the study and their initial diagnoses were analyzed, no follow-up visit details were analyzed. The gender distribution of patients attending the orthopaedic out-patient department is shown in (Figure 2). It is seen that male patients $(50.72 \%)$ attended the OPD slightly more than female patients $(49.28 \%)$ during the study period (Figure 2); it has also been observed in other studies that males attend orthopaedic OPDs more than females. ${ }^{4}$ From this we could infer that males are slightly more prone to fractures, soft tissue injuries or compromised musculoskeletal conditions as compared to females; this may be due to the maledominated areas having occupational hazards. Age of the patients included in the study was found to be from 7 years to 85 years. Mean age of all patients was found to be 51 years. Age-wise distribution of illnesses observed in the present study is documented in (Table 1). The gender-wise distribution of patients with respect to their initial diagnosis has been described in (Figure 2).

A huge difference was observed in gender-wise distribution of neuropathies; it was observed that while $70 \%$ females suffer from it, $30 \%$ males too experience neuropathic disorders. In case of sports injuries, $60 \%$ females and $40 \%$ males, suffer from it. The comparison of the present study with few other studies (Table 2). The literature review performed, revealed that there is an insufficiency of similar research data, so a particular comparison of the present study with other studies seems hard to achieve. A few similar studies are compared with the present study in (Table 2). Backaches, neck-related problems, fractures, and arthritis were common in all the studies.

No noteworthy comparisons were observed between the present study and data observed in other studies. The explanation for this high frequency of back pain could be because of increasing inactive way of life and obesity. Obesity affects nearly all age groups hence it is essential to devise clinical rules and regulations for managing common and usual issues among overweight subjects. ${ }^{7}$ Serious physical work, prolonged hours of working, mental stress, unhealthy postures, and job discontentedness also are involved in causing low backache. ${ }^{8}$ Other prime reasons for orthopaedic OPD visits were tendinopathies and enthesopathies. The chief reason for foot pain in the present study was observed to be Plantar fasciitis. Plantar fasciitis is additionally related to weight in excess and poor foot wear. The foremost common tendinopathies during this study were shoulder tendinosis and tennis elbow. Furthermore, the tennis elbow is taken into account as the foremost common reason behind elbow pain. ${ }^{9}$ Arthritis, a commonly observed disorder within the adult population, was additionally one in every of the frequent causes of orthopedic visits in our study, with osteoarthritis outnumbering the other kinds of arthritis during this study. ${ }^{10}$ Research of Chapple et al showed that development and advancement of radiographic osteoarthritis could be predicted by one's age. ${ }^{11}$ In the present study, common fraction of patients who were presented with rheumatic pain was found to be older than 40 years of age. Trauma, high body mass index, specific tough physical activities, or strenuous professions are some of the potential hazards for the onset of arthritis of the knee, hip and hand. ${ }^{12}$ A great range of sufferers is additionally provided with osteoarthritis. The occurrence of osteoarthritis is developing step by step because of poor nutritional habits, loss of exercise, and obesity. Nonspecific pain $(5.11 \%)$, inclusive of body aches and polyarthralgia was observed to be associated with undiagnosed metabolic problems and a poor lifestyle. ${ }^{13}$

Frozen shoulder is the most common cause of joint stiffness. Diabetes mellitus is most commonly associated with frozen shoulder. The combined frequency of a diabetic patient susceptible to having frozen shoulder is approximately $71.5 \% .^{14}$ Patients with diabetes have a 10\%-20\% lifetime threat of developing a frozen shoulder, with a $4 \%$ point prevalence, and a $2-4$ times increased risk than the general population. $6.92 \%$ of patients visiting the orthopaedic OPD came with neck-related pathology. 14,15-17,18 Neck muscle pain and neck spasms were found to be most common among all patients. The underlying reason behind this might be due to jobs that require 
prolonged hours of sitting at desks and also due to the increasing use of smart phones and computers owing to COVID-19 period of lifestyle. ${ }^{19,20}$ A study conducted in July 2021 showed an association between the increased use of computers and work-related neck pain. ${ }^{21}$ Thus a huge difference was observed in prevalence of various diseases during the Covid-19 period in an orthopaedicout-patient department of a tertiary care hospital.

Table 2: Comparison of the present study with few other studies.

\begin{tabular}{|c|c|c|c|c|c|}
\hline Parameters & Present study & $\begin{array}{l}\text { Kumar et al } \\
(2018)^{1}\end{array}$ & Syed et al $(2019)^{2}$ & $\begin{array}{l}\text { Gupta et al } \\
(2019)^{5}\end{array}$ & $\begin{array}{l}\text { Raj et al } \\
(2019)^{6}\end{array}$ \\
\hline Place, Country & Mumbai, India & $\begin{array}{l}\text { West Bengal, } \\
\text { India }\end{array}$ & Jeddah, Saudi Arabia & Bihar, India & $\begin{array}{l}\text { West Bengal, } \\
\text { India }\end{array}$ \\
\hline Study duration & 6 months & 3 months & 4 years & 1 year & 2 months \\
\hline Study type & $\begin{array}{l}\text { Retrospective } \\
\text { study }\end{array}$ & $\begin{array}{l}\text { Prospective } \\
\text { study }\end{array}$ & Retrospective study & $\begin{array}{l}\text { Prospective } \\
\text { study }\end{array}$ & $\begin{array}{l}\text { Prospective } \\
\text { study }\end{array}$ \\
\hline Sample size & 1605 & 200 & 23,495 & 800 & 360 \\
\hline Gender: male, female & $50.72,49.28$ & 62,38 & $82.5,17.5$ & $63.7,36.3$ & $67.7,32.3$ \\
\hline $\begin{array}{l}\text { Acute and chronic } \\
\text { backache }\end{array}$ & 27.29 & 29 & 25.9 & 28.9 & 17.2 \\
\hline $\begin{array}{l}\text { Neck-related } \\
\text { problems }\end{array}$ & 6.92 & 9 & 4.8 & 8.7 & 6.7 \\
\hline Arthritis & 26.23 & 15.5 & 10.6 & 16.1 & 18.9 \\
\hline $\begin{array}{l}\text { Tendinopathies and } \\
\text { enthesopathies }\end{array}$ & 6.60 & NA & 18.3 & NA & 7.3 \\
\hline Ligamentous sprains & 9.84 & NA & 6.4 & NA & NA \\
\hline Sports injuries & 0.93 & NA & 1 & NA & 4.7 \\
\hline $\begin{array}{l}\text { Post-operative follow- } \\
\text { up }\end{array}$ & 4.05 & NA & NA & NA & NA \\
\hline Joint stiffness & 10.03 & NA & 1.8 & NA & 3.3 \\
\hline Bone fractures & 2.37 & 3.5 & 11 & 3.6 & 8.3 \\
\hline $\begin{array}{l}\text { Non-specific body } \\
\text { ache }\end{array}$ & 5.11 & NA & 7.4 & NA & NA \\
\hline Neuropathies & 0.62 & NA & NA & NA & NA \\
\hline
\end{tabular}

Multiple alterations in health-care-seeking behavioural so ought to have contributed to modifications in observed disease incidence. Patients may have delayed or opted not to find for clinical attention for a number of reasons like the worry of contracting COVID-19, economic constraints or altruistic consideration for healthcare workers. ${ }^{22}$

Many professional firms have established and published empirical guidelines on adjusting clinical services for the duration of the COVID-19 pandemic. $^{23-25}$ It is therefore essential that decisions made by the directors, hospital administrators and management must be backed via way of means of scientific information with the intention to offer sensible projections and to better inform judicious deployment of staffing and resources.

\section{Limitations}

The study is retrospective and includes only primary diagnosis of the patients. It is a single center study and does not include treatment strategies or trauma management of the patients visiting the orthopaedic out- patient department. However, it is an approximate profile of different orthopedic problems that are common in a tertiary care hospital in the Mumbai metropolitan region.

\section{CONCLUSION}

The frequency of any orthopaedic complaints or diagnosis differs from one set up to the other due to racial, environmental, and geographical disparity. A thorough evaluation of the distribution of illnesses in a health care setting gives an efficient tool for the formulation of policies. It additionally gives possibilities for well-timed intervention to screen the development of any disorder and additionally facilitates the ultimate use of the scanty sources available. Keeping this in mind, the current study was conducted with the intention to evaluate the epidemiology of diseases among patients attending the orthopaedics out-patient department at Bhaktivedanta hospital and research institute, Mira Road. Frequent cases of backache and arthritis and least cases of sports injuries and neuropathies prevailing among patients during the COVID-19 era may be attributed to the sedentary life style developed during the COVID-19 
period. For better prevention and treatment policies, conducting public awareness campaigns could boost concerns about a healthy lifestyle by regular exercises and yoga and also by maintaining occupational safety to keep away from orthopedic conditions like lower back pain, arthritis, and body aches. This study additionally highlights the regional differences which can be vital to understand to arrive at the suitable pattern of disorders prevailing in a region and to adopt right preventive measures. Yet, several times, even after extensive investigation, one might not arrive at an etiological prognosis warranting long-term period follow-up.

\section{Funding: No funding sources}

Conflict of interest: None declared

Ethical approval: The study was approved by the institutional ethics committee

\section{REFERENCES}

1. Kumar A, Dalai C, Banerjee S. Distribution of illness of orthopaedic outpatient department in a tertiary care teaching hospital in West Bengal: a cross sectional study. Acta Orthop Scand Suppl. 2018;452:52-9

2. Syed MA, Azim SR, Baig M. Frequency of orthopedic problems among patients attending an orthopedic outpatient department: a retrospective analysis of 23495 cases. Ann Saudi Med. 2019; 39(3):172-7.

3. Gani A, Bhat S, Gupta A. Pattern and prevalence of orthopaedic outdoor patients at a tertiary level care hospital in Jammu, India. J K Sci. 2016;42:558-9.

4. Jagiasi J, Ubale T, Marfatiya H, More A, Sahu D. Etiological pattern of problems in an orthopaedics outpatient department of a tertiary care center. J Dent Med Sci. 2017:45;50-9.

5. Gupta KNP. A Study of Distribution of Orthopaedic Morbidities among Outdoor Patients in a Medical College in Bihar. Asian $J$ Med Res. 2019;8(2):OR06-8.

6. Vikash R. Morbidity pattern among patients attending Orthopedic OPD at IQ City Medical College, Durgapur. J Dent Med Sci. 2019;18(2):913.

7. Al-Shehri FS, Moqbel MM, Al-Khaldi YM, AlShahrani AM, Abu-Melha WS, Alqahtani AR, et al. Prevention and management of obesity: Saudi guideline update. Saudi J Obes. 2016;4:25-40.

8. Gupta S, Uddin Darokhan MA, Singh O, Muzaffar J. LBA As An Increasing Health Problem In India. JK Sci. 2016;18;172-6.

9. Kent S. Tennis Elbow and Prolotherapy. Available at:

https://www.naturmend.com/blog/2014/11/07/tennis -elbow-prolotherapy/. Accessed on 20 September 2021.

10. Centers for disease control and prevention. Prevalence of self-reported arthritis or chronic joint symptoms among adults--United States, 2001. Morb Mortal Wkly Rep. 2002;51:948-50.

11. Chapple CM, Nicholson H, Baxter GD, Abbott JH. Patient characteristics that predict progression of knee osteoarthritis: a systematic review of prognostic studies. Arthritis Care Res. 2011;63:1115-25.

12. Woolf AD, Pfleger B. Burden of major musculoskeletal conditions. Bull World Health Organ. 2003;81:646-56.

13. Richie AM, Francis ML. Diagnostic approach to polyarticular joint pain. Am Fam Physic. 2003;68: 1151-60.

14. Tighe CB, Oakley WS. The prevalence of a diabetic condition and adhesive capsulitis of the shoulder. South Med J. 2008;101(6):591-5.

15. Anton HA. Frozen shoulder. Can Fam Physician. 1993;39:1773-8.

16. Lundberg BJ. The frozen shoulder. Clinical and radiographical observations. The effect of manipulation under general anesthesia. Structure and glycosaminoglycan content of the joint capsule. Local bone metabolism. Acta Orthop Scand Suppl. 1969; 119:1-59.

17. Bridgman JF. Periarthritis of the shoulder and diabetes mellitus. Ann Rheum Dis. 1972;31(1):6971.

18. Thomas SJ, McDougall C, Brown ID, Jaberoo MC, Stearns A, Ashraf R, Fisher M, Kelly IG. Prevalence of symptoms and signs of shoulder problems in people with diabetes mellitus. J Shoulder Elbow Surg. 2007;16(6):748-51.

19. Miakotko L. The impact of smartphones and mobile devices on human health and life. Available at: https://www.nyu.edu/classes/keefer/waoe/miakotkol .pdf. Accessed on 20 September 2021.

20. Khatri D, Mahendrakar D. Neck pain and disability, an unwanted guest after the covid-19 pandemic outbreak! How to deal with it?. Available at: https://www.researchgate.net/publication/35307070 4_neck_pain_and_disability_an_unwanted_guest_af ter_the_covid-

19_pandemic_outbreak_how_to_deal__ with_it. Accessed on 20 September 2021.

21. Wong J, Cheung K. Impact of COVID-19 on Orthopaedic and Trauma Service. J Bone Joint Surg. 2020;102(14):e80.

22. Royal College of Surgeons. Guidance for surgeons working during the COVID-19 pandemic. 2020 Mar 20. Available at: https://www.rcseng.ac.uk/ corona virus/joint-guidance-for-surgeons-v1/. Accessed on 20 September 2021.

23. American College of Surgeons. Clinical issues and guidance. 2020. Available at: https://www.facs.org/ about-acs/covid-19/information-for-surgeons.

Accessed on 20 September 2021.

24. British Orthopaedic Association. Management of patients with urgent orthopaedic conditions and trauma during the coronavirus pandemic. 2020. Available at: https://www.boa.ac.uk/uploads/assets/ 
ee39d8a8-9457-4533-9774e973c835246d/COVID19-BOASTs-Combined-v1FINAL.pdf. Accessed on 20 September 2021.

25. National Health Service. Clinical guide for the management of trauma and orthopaedic patients during the coronavirus pandemic. 2020. Available at: https://www.england.nhs.uk/coronavirus/wpcontent/uploads/sites/52/2020/03/specialty-guide- orthopaedic-trauma-and-coronavirus-v1-16-march2020.pdf. Accessed on 20 September 2021.

Cite this article as: Rathod G, Borole P, Shetty C, Raut N, Britoo N, Gawali V. A cross-sectional study of diseases prevailing in an orthopaedic OPD at a tertiary care hospital in the Mumbai metropolitan region. Int J Res Orthop2022;8:171-6. 